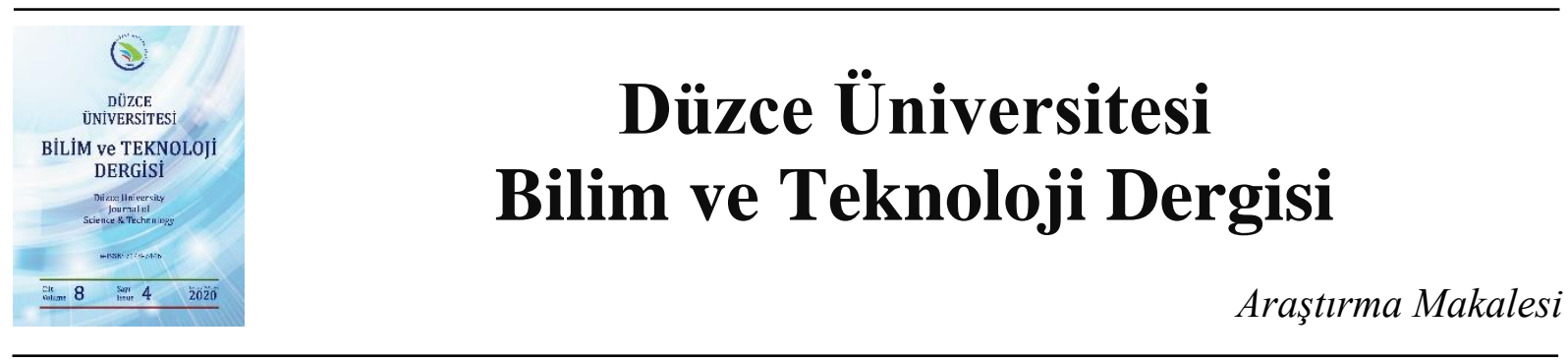

\section{Farklı Biyokütle Atıklarının Alkali Ön İşlem Etkinliklerinin İncelenmesi}

\author{
(iD) Zeynep CEYLAN ${ }^{a}$ iD Şeyda TAŞAR ${ }^{a}{ }^{*}$ iD Fatih KAYA ${ }^{a}$ iD Ahmet ÖZER $^{\text {a }}$ \\ ${ }^{a}$ Kimya Mühendisliği Bölümü, Mühendislik Fakültesi, Fırat Üniversitesi, Elazı̆̆, TÜRKİYE \\ * Sorumlu yazarın e-posta adresi: sydtasar@firat.edu.tr \\ DOI: 10.29130/dubited.702096
}

\begin{abstract}
ÖZET
$\mathrm{Bu}$ çalışmada farklı atık türlerinin sürdürülebilir biyo-rafineri yaklaşımıyla katma değeri yüksek ürünlere dönüşüm potansiyelleri karşılaştırmalı olarak incelenmeye çalışılmıştır. Bu amaçla kayısı çekirdeği kabuğu, ceviz kabuğu, şeker pancarı küspesi, çay posası ve çam odununun talaşı değerlendirilmiştir. Biyokütlenin kimyasal yapısının temel bileşenlerin (hemiselüloz, selüloz, ligninin) izolasyon verimleri üzerine etkisi araştırılmıştır. Edilen temel bileşenler (hemiselüloz ve selüloz) FTIR analizi ile karakterize edilmiş ve elde edilen spektrum literatür çerçevesinde yorumlanmıştır. Biyokütlenin lignin içeriğinin hemiselüloz ekstraksiyon verimi üzerine etkisinin olmadığı belirlenmiştir. Çay posasının hemiselüloz izolasyon veriminin (\%25), ceviz kabuğunun ise lignin izolasyon veriminin (\%19) diğer biyokütle türlerinden daha yüksek olduğu ortaya konulmuştur.
\end{abstract}

Anahtar Kelimeler: atık biyokütle kaynakları, alkali ön işlem süreci, hemiselüloz, selüloz, lignin, karakterizasyon.

\section{Isolation and Characterization of Hemicellulose and Cellulose from Various Waste Biomass Wastes}

\begin{abstract}
In this study, the potential of different types of biowaste to products with high added value was investigated through a sustainable bio-refinery approach. For this purpose, the pine wood sawdust, the walnut shell, the sugar beet pulp, the tea pulp and apricot kernel had been evaluated. The effect of chemical structure of biomass on the isolation yields of main components (hemicellulose, cellulose and lignin) were investigated. The main components were characterized with FTIR analysis and the obtained spectrums has been interpreted with the literature's. It was determined that lignin content of biomass used in this study had no effect on hemicellulose extraction yield. The tea pulp's hemicellulose yield $(25 \%)$ and the walnut shell's lignin isolation yield (19\%) were found to be higher than the other biomass types.
\end{abstract}

Keywords: waste biomass resources, alkali pretreatment process, hemicellulose, cellulose, lignin, characterization. 


\section{GIRIS}

Hızlı nüfus artışı; enerji, gıda ve ihtiyaç duyulan kimyasalların üretimi alanlarında yeni ve alternatif kaynak arayışlarını da beraberinde getirmiştir. Bu sebeple yenilenebilir lignoselülozik yapılı biyokütle kaynaklarının, özellikle de biyokütle atıklarının enerji, gıda ve değerli kimyasalların üretiminde ve sentezinde değerlendirilmesine yönelik çalışmalara hız verilmiştir.

Lignoselülozik yapılı biyokütle kaynaklarından biyo-ürün üretim sürecinde, öncelikle kompleks yapının ön işlem süreçleri ile temel bileşenlerine (selüloz, hemiselüloz, lignin) ayrıştırılması gerekmektedir. Lignoselülozik yapılı biyokütle kaynaklarının temel bileșenlerinin izolasyonu sürecinde uygulanan ön işlemler fiziksel, fizikokimyasal, kimyasal ve biyolojik işlemler olarak gruplandırılmaktadır $[1,2]$. Ön işlem süreçlerinde genel olarak, biyokütlenin boyutunun küçültülmesi, fiziksel yapısının açılması, lignin ve hemiselülozun biyokütleden uzaklaştırılması, selülozun kristalliğinin azaltılması ve gözenekli yapının artırılması amaçlanmaktadır [2]. Biyokütleye uygulanan ön işlem süreçlerinden en çok kullanılan prosesler; asit, alkali ya da asit/alkali kombine hidrolizi, oksidatif $\left(\mathrm{H}_{2} \mathrm{O}_{2}\right.$ ile) hidroliz, karbondioksit, su buharı ya da amonyak lif patlaması (AFEX) uygulamaları ve yüksek basınçta sıcak su ile oksidasyondur. Literatürde ifade edilen tekniklerle, çeşitli biyokütle türlerinden temel bileşenlerinin izolasyonu, izolasyon verimi ve izolasyon ürünlerinin değerlendirilmesi sürecini konu alan çok sayıda çalışma bulunmaktadır [3-14]. Ancak farklı kimyasal kompozisyona sahip atık türlerinin aynı şartlarda izolasyonunu karşılaştırmalı olarak araştıran bir çalışma literatürde yer almamaktadır. Biyokütle türlerinin kimyasal kompozisyonunun, temel bileşenlerin izolasyon verimi ve elde edilen temel bileşenlerin yapısı üzerine etkisini inceleyen, yorumlayan ve sunan bir çalışmaya ulaşılamamıştır.

Literatürde sunulmuş mevcut çalışmalardan farklı olarak; bu çalışmada farklı atık türlerinin sürdürülebilir biyo-rafineri yaklaşımıyla katma değeri yüksek ürünlere dönüşüm potansiyelleri karşılaştırmalı olarak incelenmiştir. Kullanılan biyokütlelerin kimyasal yapısının (özellikle holoselüloz/lignin oranının), ön işlem süreç etkinliği ve temel bileşenlerin (hemiselüloz, selüloz ve ligninin) izolasyon verimi üzerine etkisi araştırılmıştır. Bu kapsamda tarımsal atık niteliği taşıyan kayısı çekirdeği kabuğu ve ceviz kabuğu, endüstriyel atık niteliği taşıyan şeker pancarı küspesi, evsel atık niteliği taşıyan çay posası ve orman ürünleri atığı niteliği taşıyan çam odununun talaşı hammadde olarak değerlendirilmiştir. Elde edilen hemiselülozik ve selülozik fraksiyonların yapısal karakterizayonları FTIR analizleri gerçekleştirilmiştir. Ayrıca alkali ön işlem sürecinde meydana gelen morfolojik değişim SEM görüntüleri ile gözlemlenmiştir.

\section{MATERYAL VE METOD}

Beş farklı atığın sürdürülebilir biyo-rafineri yaklaşımıyla katma değeri yüksek ürünlere dönüşüm potansiyellerinin incelendiği bu çalışma, üç temel işlem adımı dikkate alınarak yürütülmüştür. Bunlar;

(i) Bitkisel atıkların temini ve karakterizasyonu

(ii) Bitkisel atıkların alkali-oksidatif metotla temel bileşenlerine fraksiyonlanması,

(iii) Elde edilen temel bileşenlerin karakterizasyonudur.

\section{A. BIYYOKÜTLE ATIKLARIN TEMINI VE KARAKTERIZASYONU}

Kayısı çekirdeği kabuğu ve ceviz kabuğu Elazı̆̆g'daki yerel işletmelerden, talaş numunesi Fırat Üniversitesi marangozhanesinden ve şeker pancarı küspesi Elazı ̆ Şeker Fabrikasından, çay posası (çay demleme sonrasında demlikte kalan posa) ise Fırat Üniversitesi bünyesindeki kantinlerden toplanarak temin edilmiştir.

Temin edilen biyokütle atıkları, polietilen brandalar üzerinde atmosferik şartlarda ön kurutma işlemine tabi tutulmuştur. Biyokütle atıkları, ön kurutma işleminden sonra $80^{\circ} \mathrm{C}$ 'de 48 saat süre ile etüvde kurutulmuş, deneysel çalışmalarda kullanılmadan önce gıda öğütücüsü (Renas marka) kullanılarak 
ögütülmüştür. Öğütülen biyokütle atıkları laboratuar ölçekli vibrasyonlu bir elek serisi kullanılarak fraksiyonlarına ayrılmıştır.

Proximate analiz: Atık biyokütle kaynaklarından elek analizi ile elde edilen $154 \mu \mathrm{m}$ (100 mesh elek alt1) parçacık boyutundaki fraksiyonu proximate analizde kullanılmıştır. ASTM standartlarına göre yapılan proximate analiz deneyleri, en az 3 paralel örnekle gerçekleştirilmiştir. Uçucu madde içeriği ASTM E 897-82, kül içeriği ise ASTM D 1102-84 standardına göre tespit edilmiştir.

Elementel analiz: Atık biyokütle örneklerinin elementel analizi (karbon, hidrojen, azot ve oksijen miktarı) ASTM standardına uygun olarak hizmet alımı yoluyla ile gerçekleştirilmiştir. Analizler İnönü Üniversitesi Bilimsel ve Teknolojik Araştırma Merkezi bünyesinde bununan, Leco CHNS-932 marka elementel analiz cihazı kullanılarak yapılmıştır.

Kimyasal Analiz: Atık biyokütle örneklerinin, kimyasal yapısını oluşturan temel bileşenlerin (ekstraktif maddeler, hemiselüloz, lignin ve selüloz) ağırlıkça yüzde bileşimleri aşağıda özetlenen işlem adımları dikkate alınarak, analitik metotlarla belirlenmiştir $[15,16]$.

(i). Ekstraktif madde tayini: İlk tartımı alınan biyokütle örneği, katı/sıvı oranı 1/10 olacak şekilde, hacim oranları 2/1 olan toluen/etanol karışımı ile 3 saat süre ile geri soğutucu altında muamele edildi. İşlem sonrası katı bakiye filtrasyon ile çözücüden ayrıldı. Etüvde $80^{\circ} \mathrm{C}$ 'de sabit tartıma gelinceye kadar kurutuldu. Atık biyokütle bünyesinde bulunan ekstraktif madde miktarı aşağıdaki eşitlik kullanılarak hesaplandı.

$W_{1}=\frac{G_{0}-G_{1}}{G_{0}}$

Burada;

$\mathrm{W}_{1}$; ekstraktif madde yüzdesini, $\mathrm{G}_{0}(\mathrm{~g})$; biyokütle örneğinin ekstraksiyon işlemi öncesindeki kütlesini, $\mathrm{G}_{1}(\mathrm{~g})$; ekstraksiyon işleminden sonra kalan kalıntının kütlesini ifade etmektedir.

(ii). Hemiselüloz tayini: Ekstraktif madde tayini sonucunda elde edilen kurutulmuş katı bakiye tartıldı, ilk tartımı kaydedilen örnek 500 mililitrelik balon jojeye alındı. Üzerine $20 \mathrm{~g} / \mathrm{L}$ konsantrasyondaki $\mathrm{NaOH}$ çözeltisinden katı/sıvı oranı 1/10 olacak şekilde ilave edilen örnek, 3.5 saat süreyle, $1200 \mathrm{rpm}$ karıştırma hızında geri soğutucu altında $\mathrm{NaOH}$ çözeltisi ile muamele edildi. İşlem sonunda katı bakiye filtrasyon ile ayrıldı, katı bakiye nötral $\mathrm{pH}$ değerine gelinceye kadar saf su ile yıkandı. Yıkanan katı bakiye etüvde sabit tartıma gelene kadar kurutuldu, son tartımı alınıp hemiselüloz içeriği aşağıdaki eşitlik yardımıyla hesaplandı.

$W_{2}=\frac{G_{1}-G_{2}}{G_{0}}$

Burada;

$\mathrm{W}_{2}$; hemiselüloz yüzdesini, $\mathrm{G}_{0}(\mathrm{~g})$; başlangıçta alınan numunenin kütlesini, $\mathrm{G}_{1}(\mathrm{~g})$; ekstraktif madde ekstraksiyon işleminden sonra kalan kalıntının kütlesini, $\mathrm{G}_{2}(\mathrm{~g})$; alkali muameleden sonra sabit tartıma getirilen katı bakiyenin kütlesini ifade etmektedir.

(iii). Lignin tayini: Ekstraktif madde miktarı tayini sonunda kalan kalıntıdan, $1.00 \mathrm{~g}$ örnek alınarak sabit tartıma getirildi. Sabit tartıma getirilen örneğin üzerine yavaşça \%72'lik $30 \mathrm{ml}$ $\mathrm{H}_{2} \mathrm{SO}_{4}$ çözeltisi eklendi ve karışım $8-15^{\circ} \mathrm{C}$ sıcaklık aralığında 24 saat süreyle bekletildi. $\mathrm{Bu}$ süre sonunda karışımın üzerine $300 \mathrm{ml}$ saf su eklendi, karışım 1 saat süreyle geri soğutucu altında kaynatıldı. İşlem sonrası katı bakiye filtrasyonla ayrıldı, sülfat iyonu kalmayana kadar saf su ile yıkandı. Baryum klorür çözeltisi ile çözelti ortamında sülfat iyonunun kalıp kalmadığı test edildi. Katı bakiye sabit tartıma gelene kadar kurutuldu ve tartıldı. Atık biyokütle bünyesindeki lignin miktarı aşağıdaki eşitlik kullanılarak hesaplandı. 
$W_{3}=\frac{G_{4}-\left(1-W_{1}\right)}{G_{3}} \times 100$

Burada;

$\mathrm{W}_{3}$; lignin yüzdesini, $\mathrm{W}_{1}$; ekstraktif madde yüzdesini, $\mathrm{G}_{3}(\mathrm{~g})$; ekstraktif madde ekstraksiyon işlemi sonucunda kalan kalıntıdan alınan örnek kütlesini (1.00), $\mathrm{G}_{4}(\mathrm{~g})$; lignin analizi sonucu sabit tartıma getirilen kalıntı kütlesini ifade etmektedir.

(iv). Selüloz miktarının hesaplanması: Her bir numunenin \%selüloz içeriği aşağıdaki eşitlik yardımı ile farktan hesaplandı.

$\mathrm{W}_{4}=100-\left(\% \mathrm{Kül}+\mathrm{W}_{1}+\mathrm{W}_{2}+\mathrm{W}_{3}\right)$

Bu eşitlikte,

$\mathrm{W}_{4}$; selüloz yüzdesini, $\mathrm{W}_{1}$; ekstraktif madde yüzdesini, $\mathrm{W}_{2}$; hemiselüloz yüzdesini, $\mathrm{W}_{3}$; lignin yüzdesini ifade etmektedir.

Fourier Transform Infrared Rezonans (FTIR) analizi: Biyokütle atıklarının yapısında bulunan fonksiyonel grupların belirlenmesi amaciyla Shimadzu IRSipirit FTIR spektrofotometresi kullanıldı. Bütün ölçümler, $400-4000 \mathrm{~cm}^{-1}$ aralığında ve 45 tarama yapılarak yürütüldü.

\section{B. BIYYOKÜTLE ATIKLARININ ALKALI EKSTRAKSIYYONU VE TEMEL BILESŞENLERIN KARAKTERIZASYONU}

Bitki hücre duvarının matrisini oluşturan selüloz, hemiselüloz ve lignin birbiriyle etkileşim halindedir. Hemiselüloz ve selüloz arasında hidrojen bağları, hemiselüloz ve lignin arasında kovalent (eter ve ester) bağları bulunmaktadır. Alkali ortamda hemiselüloz ve selüloz arasındaki hidrojen bağları kırılarak hemiselüloz çözelti ortamına alınabilir. Selüloz alkali çözeltilerde çözünmeden katı bakiyede kalır. Yürütülen çalışmada, literatürde farklı biyokütle türlerinin temel bileşenlerine ayrıştırılmasında kullanılan alkali ön işlem metodu [9, 10, 17] modifiye edilerek kullanılmış olup, uygulanan metoda ilişkin işlem adımları Şekil 1'de özetlenmiş ve aşağıda temel başlıklar şeklinde daha detaylı olarak sunulmaya çalışılmıştır.

Atık biyokütle kaynaklarından yăg ve vaksların ayrılması: $-30+50$ mesh partikül boyutundaki atık biyokütle fraksiyonu öncelikle saf su ile yıkandı. Yıkama işlemi çalkalamalı bir su banyosunda katı/sıvı oran 1:10 olacak şekilde, $60^{\circ} \mathrm{C}$ ve $120 \mathrm{rpm}$ çalkalanma hızında 6 saat süre ile gerçekleştirildi. Su ile yıkama işlemi sonunda süzülerek ayrılan katı bakiye $60{ }^{\circ} \mathrm{C}$ 'de etüvde kurutuldu. Kurutulan katı bakiyenin bünyesinde bulunan yağ, vaks ve reçineler, toluen/etanol $(2 / 1(\mathrm{v} / \mathrm{v}))$ karışımı ile soxhlet ekstrakstraktörü kullanılarak ayrıştırıldı. Ekstraksiyon süresi 6 saat'dir. Ekstraksiyon işlemi sonrası kartuş içerisinde kalan ekstraktif maddelerden arındırılmış katı bakiye etüvde $60{ }^{\circ} \mathrm{C}$ sıcaklıkta 12 saat süreyle kurutuldu.

Alkali ekstraksiyon ile selülozun kazanılması: Karbonhidrat bakımından zengin bakiye $10 \mathrm{~g} / \mathrm{L}$ konsantrasyonundaki $\mathrm{NaOH}$ çözeltisi ile muamele edildi. İşlemler sonucu katı bakiye filtrasyon ile ayrıldı ve nötral $\mathrm{pH}$ 'ya kadar saf su ile yıkandı. Yıkama işlemi sonunda elde edilen katı bakiye yani "selüloz" etüvde $60^{\circ} \mathrm{C}$ 'de 24 saat kurutuldu. Son adımda kurutulan selüloz gıda öğütücüsünde öğütüldü ve ağzı kapaklı numune kaplarında muhafaza edildi.

Lignin ve hemiselülozun çözeltiden kazanılması: Selüloz ayrıldıktan sonra geriye kalan filtratın $\mathrm{pH}$ değeri $4 \mathrm{M} \mathrm{HCl} \mathrm{çözeltisi} \mathrm{ile} \mathrm{yaklaşık} \mathrm{5.0-5.5} \mathrm{civarına} \mathrm{getirildi,} \mathrm{süzüntü} \mathrm{miktarının} 3$ katı kadar etanol eklenip hemiselülozun teşekkülü sağlandı. Hemiselüloz santrifüjlenerek sıvıdan ayrıldı. Elde edilen hemiselüloz etanol ile en az üç kez yıkand 1 ve $60^{\circ} \mathrm{C}$ 'de etüvde kurutuldu. Santrifüjleme işlemi sonucunda kalan filtratın içerdiği etanol döner buharlaştırıcı kullanılarak uzaklaştırıldı. 


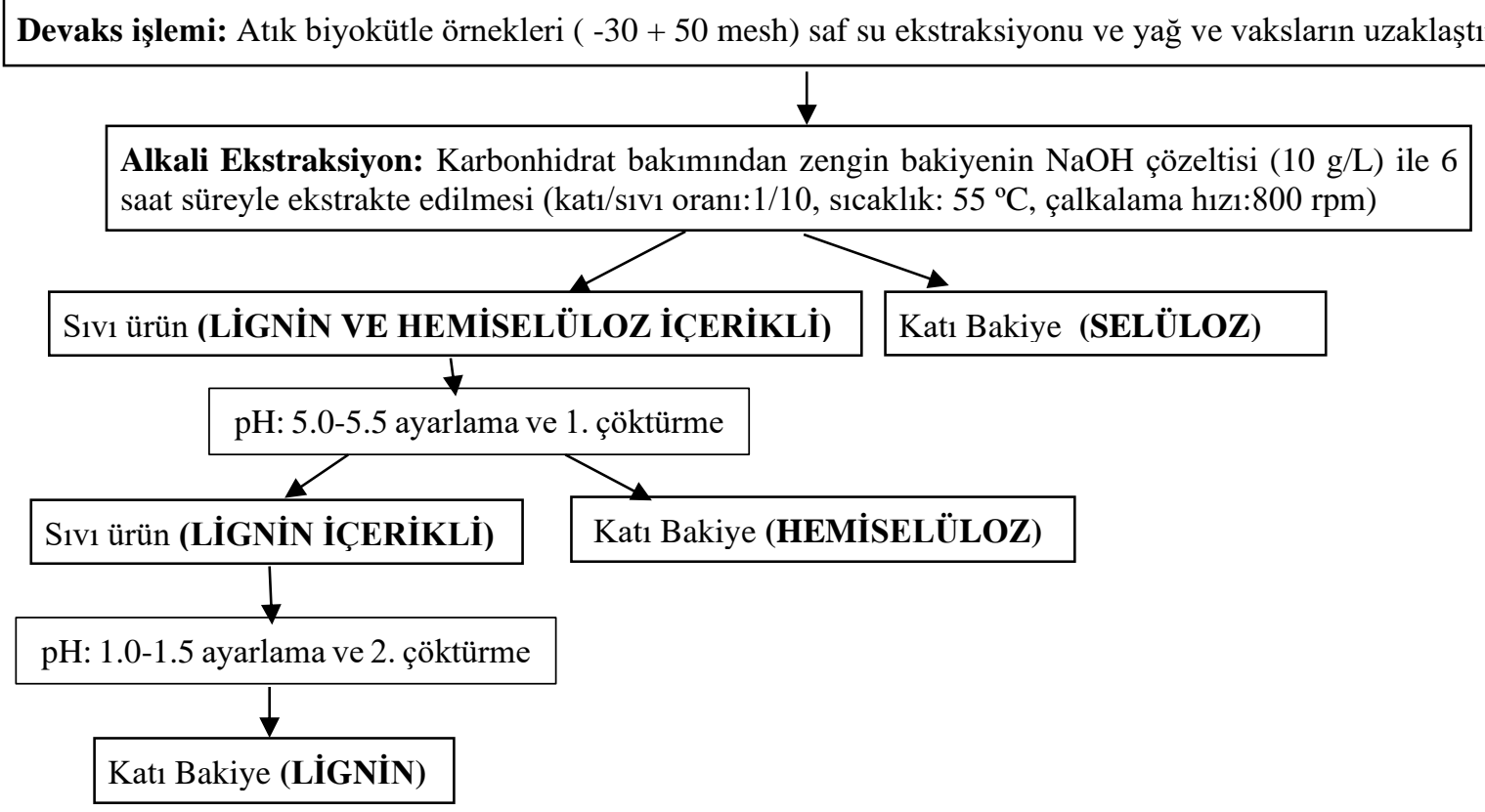

Şekil 1. Temel bileşenlerin alkali-oksidatif proseslerle ayrıştırılmasına iliş̧kin işlem adımları.

Elde edilen derişik çözeltinin pH değeri 1.5-2'ye ayarlandı, süzüntü miktarının 3 katı kadar etanol eklenip lignin teşekkülü sağlandı. Lignin de santrifüjleme işlemi ile filtrattan ayrıldı. $60^{\circ} \mathrm{C}$ 'de etüvde kurutuldu ve gıda öğütücüsü yardımıyla ögütüldü ve ağzı kapaklı numune kaplarında muhafaza edildi.

Temel bileșenlerin karakterizasyonu: Yukarıda ifade edilen metodoloji ile ayrıştırılan selüloz ve hemiselülozun yapısı FTIR analizleri ile belirlendi. Analizler Fırat Üniversitesi Kimya Mühendisliği bölümünde yer alan Shimadzu IRSipirit FTIR spektrofotometresi kullanılarak gerçekleştirildi. Tüm ölçümler, 400 ila $4000 \mathrm{~cm}^{-1}$ aralığında 45 tarama yapılarak gerçekleştirildi. Alkali ön işlem sırasında atık biyokütle örneklerinin yüzey morfolojisinde meydana gelen değişimi belirlemek ve işlem etkinliğini daha etkin olarak gözlemleyebilmek için SEM analizleri yapıldı. Bu amaçla, JEOL JSM 7001F marka taramalı elektron mikroskobu (SEM) kullanıldı.

\section{BULGULAR VE TARTISMA}

\section{A. HAMMEDDELERIN KARAKTERIZASYONU}

Farkı biyokütle atıklarını alkali ön işlem süreci ile temel bileşenlerine ayrıştırmak ve temel bileşenleri karakterize etmek amacıyla yürütülen çalışmanın ilk adımında, temin edilen hammaddeler fiziksel işlemlere (kurutma, öğütme ve elek analizi) tabi tutulmuş ve fraksiyonlarına ayrılmıştır. Fraksiyonlama işlemi sonucu elde edilen -30+50 mesh partikül boyutuna sahip numunelerin fotoğrafları Şekil 2'de verilmiştir.

Atık biyokütle kaynaklarının proximate analiz (uçucu madde, nem, kül, sabit karbon içeriği) sonuçları Tablo 1'de; elementel bileşimi (C, H, O, S, N) Tablo 2'de verilmiştir. Kimyasal bileşimi (hemiselüloz, selüloz, lignin ve ekstraktif madde içeriği) ise Tablo 3'de özetlenmeye çalışılmıştır. 

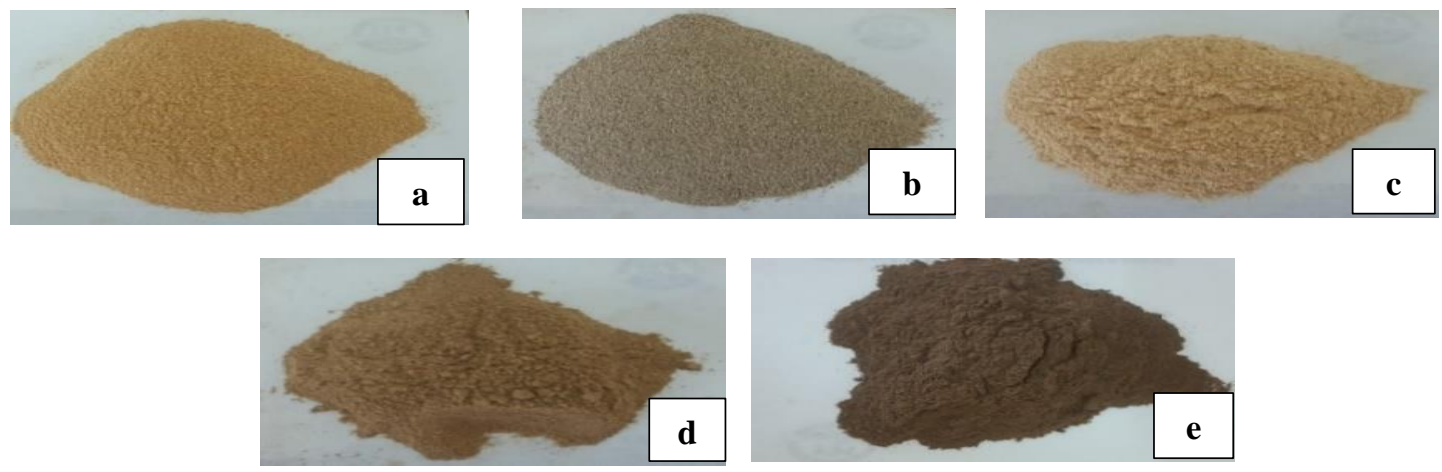

Şekil 2. Çalışmada kullanılan atık biyokütle kaynakları (a) kayısı çekirdeği kabuğu (b) Şeker pancarı küspesi (c) Çam odun talaşı $(\boldsymbol{d})$ ceviz kabuğu (e) çay posası

Tablo 1 incelendiğinde çalışmada kullanılan atık biyokütle örneklerinin uçucu madde miktarlarının genel olarak yüksek olduğu görülmektedir. En yüksek uçucu madde oranı $\% 77.05$ ile çam talaşında tespit edilmiştir. Bu sonuç çamın reçineli yapısından kaynaklanmaktadır. En düşük uçucu madde oranı (\%73.45) ise nem içeriği diğer biyokütle türlerinden oldukça yüksek olan şeker pancarı küspesinde tespit edilmiştir. Numunelerin kül içerikleri beklenen sınırlar içerisinde olmakla birlikte, kayısı çekirdeği kabuğunun kül içeriğinin diğer atıklara kıyasla oldukça düşük olduğu saptanmıştır. Bu sonuç diğer atık biyokütle kaynaklarına kıyasla, kaysı çekirdeği kabuğunun inorganik madde muhteviyatının daha düşük olduğu şeklinde yorumlanmıştır. Biyokütle örneklerinin sabit karbon içeriklerinin ise \%15 ile \%19 arasında değiştiği tespit edilmiş̧tir.

Tablo 2'de sunulan biyokütle atıklarının elementel analiz sonuçları irdelendiğinde, örneklerin elementel bileşimlerinin birbirlerine oldukça yakın olduğu görülmekle birlikte, çay posasının \%C oranının, çam odun talaşının $\% \mathrm{H}$ oranının ve şeker pancarı küspesinin ise $\% \mathrm{O}$ oranının diğer atıklardan daha yüksek olduğu göze çarpmaktadır. Çay posasının \%C içeriğinin yüksek oluşu, proximate analiz sonucunda elde edilen en yüksek sabit karbon muhteviyatına sahip olduğu sonucu ile tutarlılık içerisindedir. Şeker pancarı küspesinin oksijen muhteviyatının yüksek oluşu ise, diğer biyoktüle örneklerine kıyasla daha yüksek "uçucu madde + nem" oranına sahip olması ile uygunluk göstermektedir. Bu kapsamda biyokütle atıklarının elementel analiz sonuçları ile proximate analiz sonuçları arasında tutarlılık olduğu, analiz sonuçlarının birbirlerini destekledikleri görülmektedir.

Tablo 1. Biyokütle kaynaklarının proximate analizi (\%ağırlıkça)

\begin{tabular}{lccccc} 
Kısa Analiz & Çay posası & $\begin{array}{c}\text { Kayısı } \\
\text { çekirdeği k. }\end{array}$ & Talaş & $\begin{array}{c}\text { Şeker p. } \\
\text { küspesi }\end{array}$ & $\begin{array}{c}\text { Ceviz } \\
\text { kabuğu }\end{array}$ \\
\hline Uçucu Madde (\%) & 73.65 & 76.50 & 77.05 & 73.45 & 75.40 \\
\hline Kül (\%) & 3.420 & 0.750 & 2.900 & 2.680 & 2.930 \\
\hline Nem (\%) & 3.700 & 4.650 & 3.500 & 8.840 & 3.000 \\
\hline Sabit C* (\%) & 19.23 & 18.10 & 16.55 & 15.03 & 18.67 \\
\hline Uçucu M + Nem (\%) & 77.35 & 81.15 & 80.55 & 82.29 & 78.40
\end{tabular}

*: Farktan hesapland1

Tablo 2. Kuru temel üzerinden biyokütle kaynaklarının elementel analizi (\%ă̆ırlıkça)

\begin{tabular}{cccccc} 
Elementel Analiz & Çay posası & $\begin{array}{c}\text { Kayısı } \\
\text { çekirdeği k. }\end{array}$ & Talaş & $\begin{array}{c}\text { Şeker p. } \\
\text { küspesi }\end{array}$ & $\begin{array}{c}\text { Ceviz } \\
\text { kabuğu }\end{array}$ \\
\hline $\mathbf{C}$ & 48.55 & 47.50 & 47.24 & 41.11 & 46.75 \\
\hline $\mathbf{H}$ & 5.824 & 5.414 & 5.898 & 5.067 & 5.161 \\
\hline $\mathbf{N}$ & 3.474 & 0.200 & 0.361 & 1.353 & 0.269 \\
\hline $\mathbf{O}^{*}$ & 42.15 & 46.89 & 46.50 & 52.47 & 47.82 \\
\hline $\mathbf{S}$ & - & - & - & - & - \\
\hline $\mathbf{H} / \mathbf{C}$ & 0.12 & 0.11 & 0.12 & 0.12 & 0.11 \\
\hline $\mathbf{N} / \mathbf{C}$ & 0.07 & 0.00 & 0.01 & 0.03 & 0.01
\end{tabular}

*: Farktan hesapland1 
Tablo 3. Atık biyokütle türlerinin kimyasal analizi (\%ă̆ırlıkça)

\begin{tabular}{lccccc} 
Kimyasal Analiz & $\begin{array}{c}\text { Çay } \\
\text { posası }\end{array}$ & $\begin{array}{c}\text { Kayısı } \\
\text { çekirdeği k. }\end{array}$ & Talaş & $\begin{array}{c}\text { Şeker p. } \\
\text { küspesi }\end{array}$ & $\begin{array}{c}\text { Ceviz } \\
\text { kabuğu }\end{array}$ \\
\hline Ekstraktif madde & 10.03 & 5.074 & 12.50 & 11.20 & 7.710 \\
\hline Hemiselüloz & 37.20 & 30.16 & 7.800 & 27.60 & 26.06 \\
\hline Selüloz* & 24.93 & 33.87 & 46.50 & 41.02 & 26.40 \\
\hline Lignin & 24.42 & 30.15 & 30.30 & 17.50 & 36.90 \\
\hline Kül & 3.420 & 0.750 & 2.900 & 2.680 & 2.930 \\
\hline $\begin{array}{l}\text { Holoselüloz (Selüloz+Hemiselüloz) } \\
\text { *: Farktan hesapland1. }\end{array}$ & 62.13 & 64.03 & 54.30 & 68.62 & 52.46 \\
& & & & &
\end{tabular}

Çalışmada kullanılan lignoselülozik yapılı atık biyokütlelerin \%5-13 ekstraktif madde, \%53-65 holoselüloz ve \%17-40 oranında lignin ihtiva ettiği Tablo 3'de görülmektedir. Büyüme koşulları (iklim, ortalama sıcaklık, toprak cinsi, rakım vb.) ve biyokütle türüne bağlı olarak biyokütle kaynaklarının kimyasal bileşim yönünden farklılık gösterdiği deneysel olarak da ortaya koyulmuştur. Tablo 3 incelendiğinde; çam odun talaşının ekstraktif madde içeriğinin diğer atıklardan daha yüksek olduğu dikkat çekmektedir. Bu durum proximate analiz ile belirlenen uçucu madde içeriğinin de diğer atıklardan yüksek oluşu ile uygunluk arz etmektedir. Bu durum çam odun talaşının reçine ve vaks muhteviyatının yüksek olmasından kaynaklanmaktadır.

Atık biyokütle örneklerinin kimyasal bileşimleri daha kapsamlı olarak irdelendiğinde; çay posasının hemiselüloz oranı $\% 37.20$, talaş numunesinin selüloz oranı $\% 46.5$ ve ceviz kabuğunun ise lignin oranı \%36.90 olarak tespit edilmiştir. Bu değerlerin yüksek olması ilk etapta, çay posasının hemiselüloz, talaş numunesinin selüloz ve ceviz kabuğunun ise lignin kaynağı olarak değerlendirilebileceği şeklinde yorumlanabilir. Ayrıca, kimyasal analiz sonucu elde edilen lignin muhteviyatının (şeker p küspesi hariç) literatürde ifade edilen kritik lignin içeriğinden ( $>\% 18)$ yüksek oluşu, temel bileșenlerin ayrıștırması için alkali ön işleme ilave olarak oksidatif ajana da ihtiyaç duyulacağı, yani etkili bir izolasyon için alkali ön işlemin tek başına yeterli olmayacağı konusunda bize ön bilgi sunmuştur $[17,18]$.

Şekil 3'de biyokütle atıklarının FTIR spektrumları karşılaş̧ırmalı olarak sunulmuştur. FTIR spektrumları incelendiğinde, biyokütle örneklerinin birbirlerine benzer temel pikler içerdiği saptanmıştır. FTIR spektrumlarında gözlemlenen temel pikler ve atık biyokütle kaynaklarının kimyasal yapısı aşă̆ıdaki şekilde özetlenebilir;

$3100-3515 \mathrm{~cm}^{-1}$ aralığında gözlemlenen yayvan pik selüloz ve lignin moleküllerindeki $-\mathrm{OH}$ gruplarının gerilme titreşimini, 2921-2856 $\mathrm{cm}^{-1}$ bölgesindeki pikler alifatik $-\mathrm{CH}_{3},=\mathrm{CH}_{2}$ gruplarının asimetrik C-H gerilmesini, $1743 \mathrm{~cm}^{-1}$ piki ise hemiselülozun $\mathrm{C}=\mathrm{O}$ gerilme titreşimini temsil etmektedir [19]. $1644 \mathrm{~cm}^{-}$ ${ }^{1}$ piki ligninin karbonil gruplarının $\mathrm{C}=\mathrm{O}$ bağının gerilme titreşimine, $1560 \mathrm{~cm}^{-1}$ piki ise ligninin aromatik halka yapısındaki etilenin $(-\mathrm{C}=\mathrm{C}-)^{-}$gerilme titreșimine işaret etmektedir [20]. $1446 \mathrm{~cm}^{-1}$ 'de gözlenen pik ligninin alifatik kısımlarından kaynaklanan $-\mathrm{CH}_{3}$ gruplarının $\mathrm{C}-\mathrm{H}$ deformasyon titreşimini, $1367 \mathrm{~cm}^{-}$ ${ }^{1}$ 'deki pik metil ve fenil alkollerin alifatik $\mathrm{C}$-H eğilme titreşimini; $1239 \mathrm{~cm}^{-1}$ 'deki pik lignin ve ksilanın halka yapısındaki $\mathrm{C}-\mathrm{O}$ gerilme titreşimini; $1145 \mathrm{~cm}^{-1}$ de meydana gelen tepe, tipik ise 4-Ometilglukuronoksilan yapısını temsil etmektedir [21]. $1037 \mathrm{~cm}^{-1}$ deki pik selüloz ve hemiselülozun COH gerilme titreşimidir [20].

Çalışmada hammadde olarak kullanılan atık biyokütle kaynaklarının FTIR spektrumlarında belirlenen ve irdelenen temel pikler, Samanta vd. (2012) [22], Nizamuddin vd. (2017) [23], Pirbazarı vd. (2015) [24], Shi ve Li (2012) [125], She vd., 2009[26] ve Büyükdere (2011) [27], tarafindan yapılan farklı biyokütle türleri için elde edilen ve sunulan spektrumlar ile paralellik arz etmektedir. 


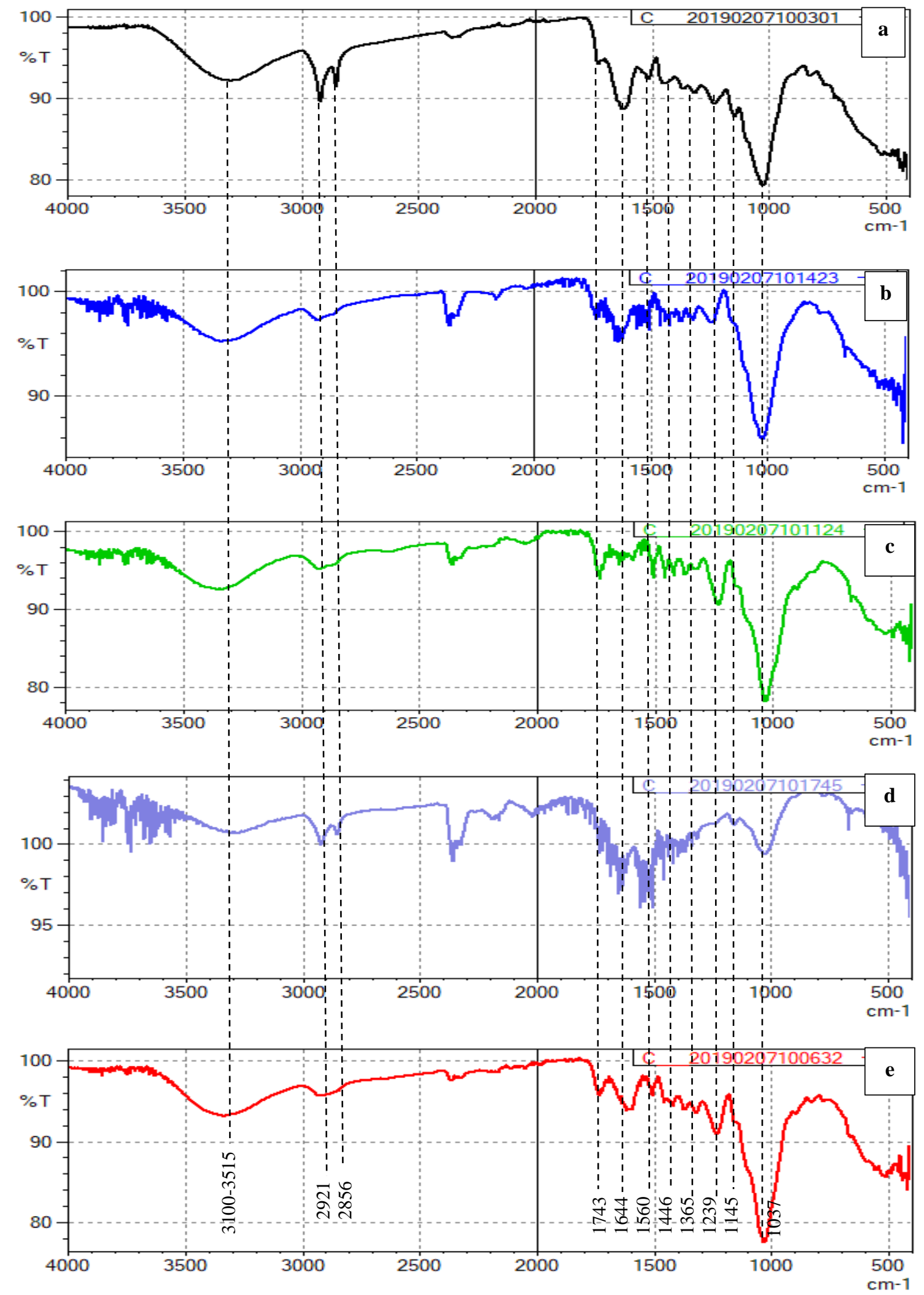

Şekil 3. Atık biyokütle kaynaklarının FTIR spektrumları (a) çay posası (b) kayısı çekirdeği kabuğu (c) talaş (d) şeker pancarı küspesi (e) ceviz kabuğu 


\section{B. ATIKLARIN TEMEL BILLEŞENLERINE AYRIŞTIRILMASINA}

Hammaddelerin yapısındaki ektraktif maddelerin biyokütlelerin yapısından uzaklaştırılması amacı ile uygulanan devaks işleminde elde edilen ekstraksiyon verimleri Şekil 4'de sunulmuştur. Ekstraktif madde ekstraksiyon veriminin en yüksek olduğu atık, (\%12.59) çam odun talaşıdır, ekstraktif madde ekstraksiyon veriminin en düşük olduğu atık ise (\%5.41) kayısı çekirdeği kabuğudur. Ekstraktif madde verimlerinin, Tablo 3 özetlenen atık biyokütle türlerinin kimyasal analizi sonucu elde edilen ekstraktif madde içerikleri ile uygunluk içerisinde olduğu belirlenmiştir. Uygulanan devaks işlemi ile biyokütle atıklarının bünyesinde bulunan ekstraktif maddelerin tamamen uzaklaştırılabildiği belirlenmiştir. İşlemin uygulandığı proses şartlarında (Toluen/etanol:2/1(v/v), 6 saat, soxhlet ekstraktörü ile, katı/sıv1 oranı: 1/10) biyokütle örneklerinin bünyesinden reçine vaks, yağ, tanen vb maddelerin başarılı olarak ayrıştırılabildiği, yani ekstraksiyon süresinin ve çözücü konsantrasyonunun yeterli olduğu sonucuna varılmıştır.

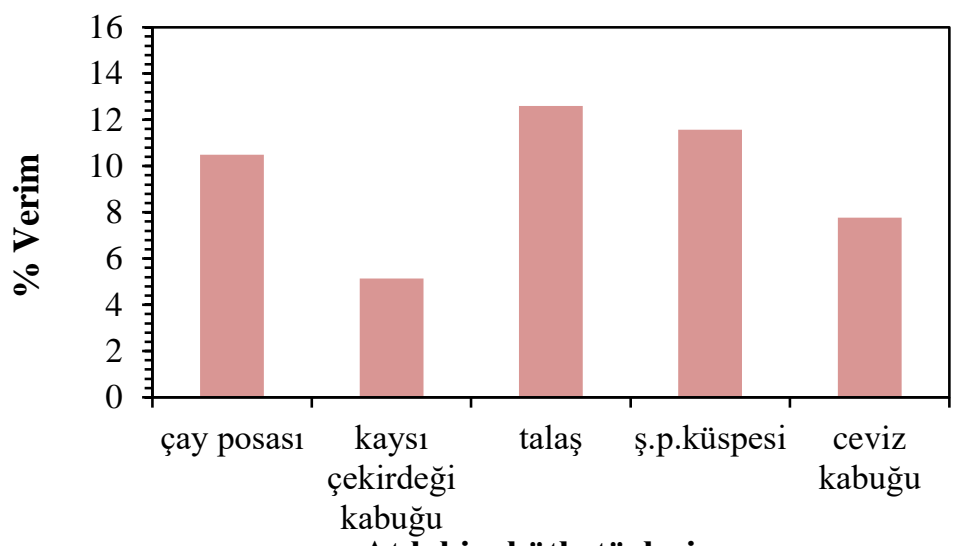

Şekil 4. Atık biyokütle kaynaklarının ekstraktif madde ekstraksiyonu işlem sürecine ilişkin izolasyon verimleri (Toluen/etanol:2/1(v/v), 6 saat, soxhlet ekstraktörü ile, katı/sıvı oranı: 1/10)

Atık biyokütle kaynaklarının yapısındaki suda çözünebilen hemiselüloz ve ligninin miktarının belirlenmesi için yürütülen sıcak distile su ekstraksiyonu sürecinde elde edilen ekstraksiyon verimleri Şekil 5'te sunulmuştur. Sicak su ekstraksiyonu ile kazanılabilen hemiselüloz verimi hammaddeye göre $\% 1.73$ ile \%2.65 değerleri arasında değişmektedir. Kazanılan hemiselüloz ve lignin verimlerinin Tablo 3 'te sunulan hammaddelerin kimyasal bileşimlerinden oldukça düşük olmasının sebebi, bu işlem sürecinde kimyasal analiz sürecinden farklı olarak alkali çözeltilerin değil, sıcak distile suyun çözücü olarak kullanılmasıdır. Deneysel sonuçlardan da görüldüğü gibi sıcak distile su ortamında hemiselüloz ve ligninin çözünürlüğünün oldukça sınırlı düzeyde kalmıştır.

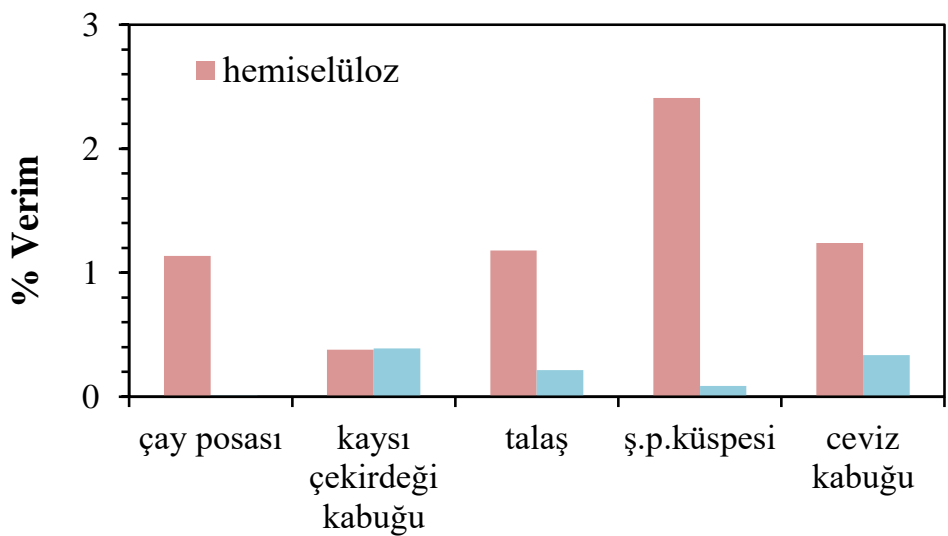

Atık biyokütle türleri

Şekil 5. Atık biyokütle kaynaklarının saf su ekstraksiyon sürecine ilişkin izolasyon verimleri (katı/sıvı oranı 1:10, sıcaklık: $60^{\circ} \mathrm{C}$, çalkalama hızı:120 rpm, süre:6 saat) 
Suda çözünebilen hemiselüloz muhteviyatı en düşük (\%0.38) olan atık kayısı çekirdeği kabuğu, en yüksek (\%2.41) olan atık ise şeker pancarı küspesidir. Sıcak su ekstraksiyonu ile kazanılabilen lignin yüzdesinin ise \%0.01 ile \%0.37 arasında değiştiği tespit edilmiştir. Suda çözünen lignin yüzdesi en düşük olan $(\% 0.01)$ atık çay posası, en yüksek olan $(\% 0.39)$ atık kayısı çekirdeği kabuğudur. Çay posasının suda çözünen "lignin+hemiselüloz" miktarının diğer biyokütle kaynaklarına göre daha düşük olması, çalışmada kullanılan çay posasının demleme atığı olmasından kaynaklanmaktadır. Tarla atığı ya da çay fabrikası paketleme atığı niteliğindeki atık çayın, suda çözünen hemiselüloz ve lignin miktarlarının bu çalışmada elde edilen sonuçlardan çok daha yüksek olacağı ön görülmektedir.

Atık biyokütle türlerinin yapısında bulunan ve alkali ortamda çözünen hemiselüloz ve lignin içerikleri Şekil 6'da sunulmuştur. Çay posası, kayısı çekirdeği kabuğu, talaş, şeker pancarı küspesi ve ceviz kabuğu için sırasıyla hemiselüloz izolasyon verimlerinin hammadde temeli üzerinden $\% 24.58, \% 19.20$, $\% 5.08, \% 18.2$ ve $\% 16.42$ olduğu tespit edilmiştir. Tablo 3 'te sunulan atık biyokütle örneklerinin hemiselüloz içerikleri baz alındığında, biyokütle örneklerinin bünyesindeki hemiselülozun yaklaşık \%66-63'ünün izole edilebildiği hesaplanmıştır.

Hemiselüloz izolasyon verimlerinin, Tablo 3 'te sunulan biyokütle türlerinin lignin muhteviyatları ile lineer bir ilişkisinin olmadığı sonucuna varılmıştır. Fakat, çalışılan atık biyokütle örneklerinin lignin muhteviyatlarının yüksek oluşunun, hemiselülozun çözünürlügünü önemli ölçüde düşürdüğg̈, alkali ön işlem ile mevcut hemiselülozun ancak \%66'nın kazanılabildiği tespit edilmiştir. Alkali ekstraksiyonun tek başına yeterli olmadığı, hemiselüloz ekstraksiyon verimini arttırmak için oksidatif bir bileşen kullanılması gerektiği sonucuna varılmıştır.

Çalışılan şartlarda çay posası, kayısı çekirdeği kabuğu, talaş, şeker pancarı küspesi ve ceviz kabuğu için sırasiyla lignin izolasyon verimlerinin hammadde temeli üzerinden $\% 16.33, \% 17.67, \% 16.80, \% 13.11$ ve \%19.56 olduğu belirlenmiştir. Tablo 3'te sunulan atıkların toplam lignin muhteviyatı dikkate alındığında, izole edilerek kazanılabilen lignin miktarları aynı sıra ile \%62.78, \%55.29, \%52.19, \%69.20 ve \%50.30 olarak belirlenmiştir. Sonuç olarak, atık biyokütle türlerinin lignin içeriğinin izolasyon verimlerini etkileyen önemli bir parametre olduğu, beklenenin aksine liginin izolasyon veriminin hammaddelerin lignin içeriğinin ile ters orantılı olduğu tespit edilmiştir.

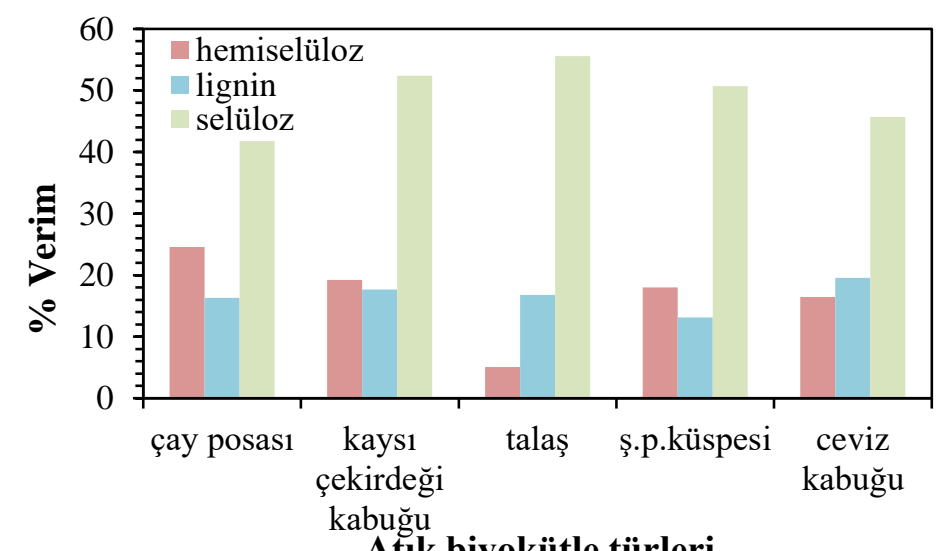

Şekil 6. Atık biyokütle kaynaklarının alkali (NaOH) ekstraksiyon sürecine iliş̧kin izolasyon verimleri ( $\mathrm{NaOH}$ çözelti konsantrasyonu: $10 \mathrm{~g} / \mathrm{L}$, süre:6 saat, katı/sıvı oranı:1/10, sıcaklık: $55^{\circ} \mathrm{C}$, çalkalama hızı:800 rpm)

\section{TEMEL BİLEŞENLERIN FTIR SPEKTRUMLARI}

Atık biyokütle kaynaklarından alkali ön işlem ile kazanılan hemiselülozik fraksiyonlarına ait FTIR spektrumları Şekil 7'de, selülozik fraksiyonlarına ait FTIR spektrumları ise Şekil 8'de sunulmuştur. Spektrumlarda gözlemlenen başlıca pikler ve temsil ettiği gruplar hemiselülozik fraksiyonlar için Tablo 4'de, selülozik fraksiyonlar için ise Tablo 5'de özetlenmiştir. 


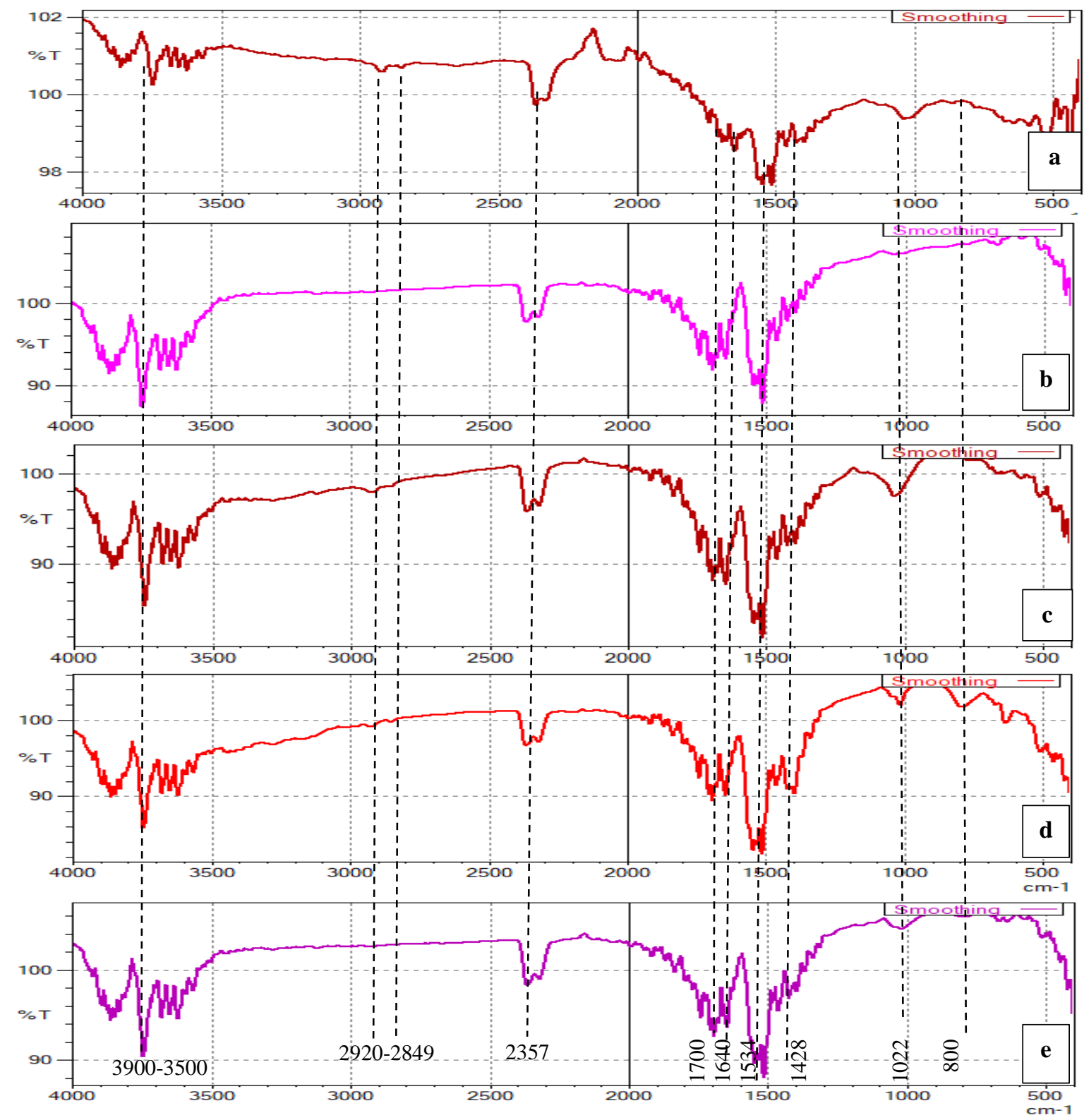

Şekil 7. Atık biyokütle kaynaklarından izole edilen hemiselülozların FTIR spektrumları(a) çay posası (b) kayısı çekirdeği kabuğu (c) talaş (d) şeker pancarı küspesi (e) ceviz kabuğu

Tablo 4. Hemiselülozik fraksiyonda gözlemlenen temel pikler [28-35]

\begin{tabular}{ll}
$3900-3500 \mathrm{~cm}^{-1}$ & Hidroksil gerilmesidir. \\
\hline $2920-2849 \mathrm{~cm}^{-1}$ & Metil ve metilen gruplarındaki C-H gerilmesidir(Karakteristik hemiselüloz piki) \\
\hline $2357 \mathrm{~cm}^{-1}$ & Tipik ksilan yapısına ait bandlardır. \\
\hline $1700 \mathrm{~cm}^{-1}$ & Karbonil gerilmesinin karakteristik zirvesidir. \\
\hline $1640 \mathrm{~cm}^{-1}$ & Sorbe edilen suya atfedilir, hemiselüloz suya karşı güçlü bir afiniteye sahiptir. \\
\hline $1534 \mathrm{~cm}^{-1}$ & Ligninin aromatik iskeletinin varlığına işaret etmektedir. \\
\hline $1428 \mathrm{~cm}^{-1}$ & C-H ve C-O büküm veya gerilme titreşimleridir. Bu pik, hemiselülozlara bağlı \\
& üronik asitlerdeki veya asetil gruplarındaki karbonil gruplarından \\
& kaynaklanmaktadır.
\end{tabular}


Şekil 7'de sunulan hemiselülozik fraksiyonlara ait pikler incelendiğinde, hepsinde aynı temel piklerin gözlemlendiği tespit edilmiştir. Spektrumda gözlemlenen başlıca pikler ve temsil ettiği gruplar, Xiao vd., (2011) [28], Egüés (2013) [29], Sun vd., (2004)[30], Briennzo (2009)[31], Sun ve Tomkinson (2002)[232], Buranov ve Mazza (2008)[33] tarafından yapılan çalışmalar elde edilen hemiselülozik fraksiyonların FTIR spektrumlarında da gözlemlenmiş ve benzer şekilde yorumlamıştır. $\mathrm{C}=\mathrm{O}$ pikinin, $1700 \mathrm{~cm}^{-1}$ bölgesinde gözlemlenmesi yapının su sorbe ettiğine işaret etmektedir [34, 35]. Spektrumlarda $1534 \mathrm{~cm}^{-1}$ de pik görülmesi ligninin aromatik iskeletinin varlığına işaret etmektedir. İki aşamalı olarak yürütülen çöktürme esnasında lignin fraksiyonunun hemiselülozik fraksiyona az da olsa karıştığı, hemiselülozun safiyetinin düştüğü anlaşılmaktadır. Ligninin hemiselülozik kısımdan tamamen uzaklaştırılamadığı FTIR spektrumu ile ortaya konulmuştur.

Şekil 8'da sunulan selülozik fraksiyonlara ait temel pikler irdelendiğinde, hemiselülozik fraksiyonda olduğu gibi benzerlik gösterdiği yani piklerin örtüştüğü görülmektedir. Spektrumda gözlemlenen başlica pikler ve temsil ettiği gruplar Tablo 5'de sunulmuştur. Tespit edilen pikler, literatürde sunulan farklı biyokütle kaynaklarından izole edilerek kazanılan selülozik fraksiyonlar için tespit edilen pikler ile uyumludur [35-38].

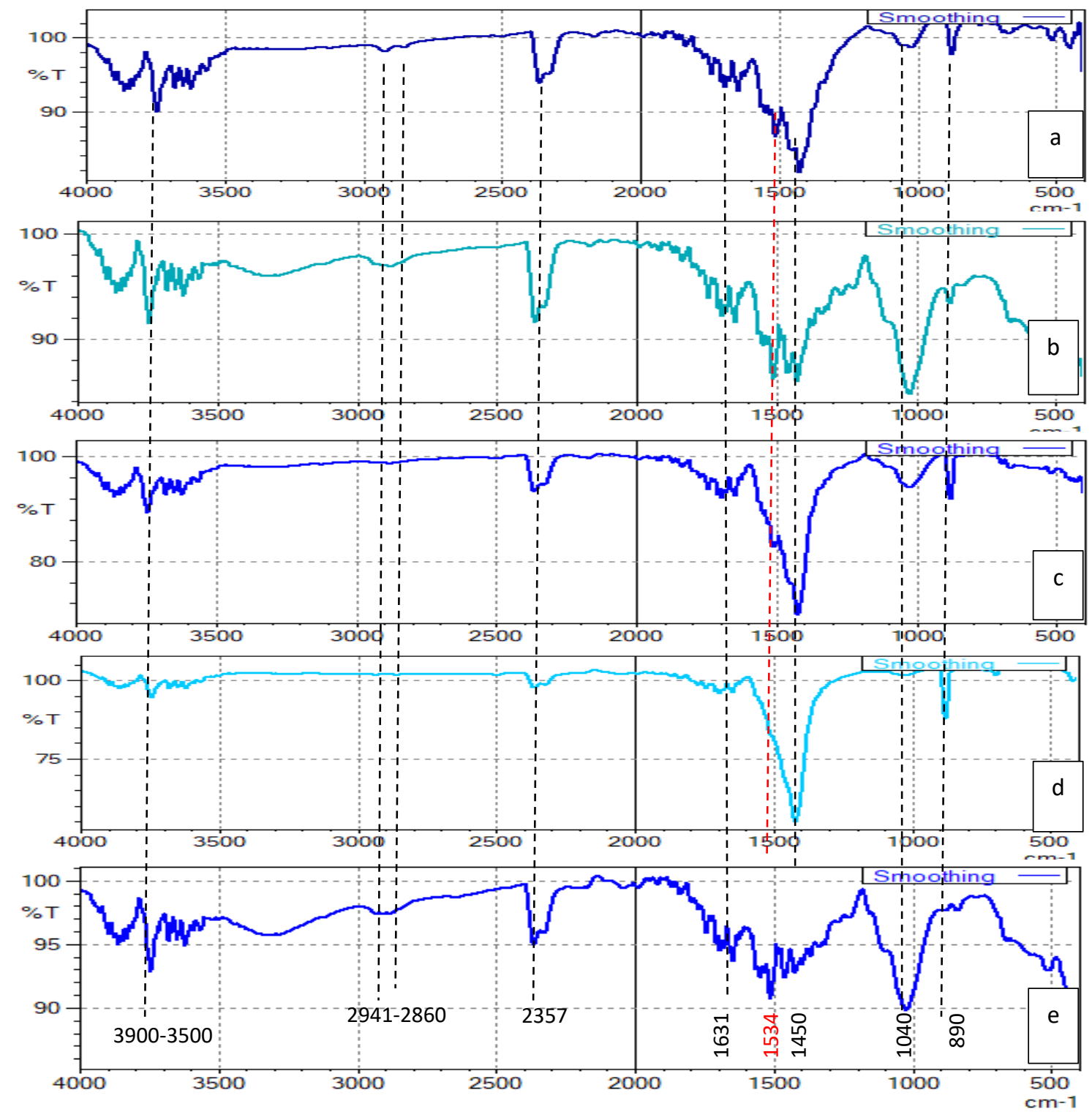

Şekil 8. Atık biyokütle kaynaklarından izole edilen selülozların FTIR spektrumları (a) çay posası (b) kayısı çekirdeği kabuğu (c) talaş (d) şeker pancarı küspesi (e) ceviz kabuğu 
Tablo 5. Selülozik fraksiyonda gözlemlenen temel pikler[35-38]

\begin{tabular}{ll}
$3900-3500 \mathrm{~cm}^{-1}$ & $\begin{array}{l}\text { O-H gerilmesi; selüloz matriksinde tekrarlayan birimler arasındaki hidrojen } \\
\text { bağlarılya bir arada bulunan O-H gruplarına aittir. }\end{array}$ \\
\hline $2940 \mathrm{~cm}^{-1}$ & Karakteristik C-H gerilmesi \\
\hline $2860 \mathrm{~cm}^{-1}$ & $=\mathrm{CH}_{2}$ ve $-\mathrm{CH}_{3}$ titreşimlerini \\
& $\alpha$-selülozun C-H grupları gerilimini ifade etmektedir. \\
\hline $2357 \mathrm{~cm}^{-1}$ & Tipik ksilan yapısına ait bandlardır. \\
\hline $1630 \mathrm{~cm}^{-1}$ & $\mathrm{C}=\mathrm{O}$ titreşimi fonksiyonel grubuna aittir \\
\hline $1450 \mathrm{~cm}^{-1}$ & C-H ve C-O büküm veya gerilme titreşimleridir. Bu pik, hemiselülozlara bağlı \\
& üronik asitlerdeki veya asetil gruplarındaki karbonil gruplarından \\
& kaynaklanmıştır.
\end{tabular}

Spektrumda $1040 \mathrm{~cm}^{-1}$ civarında pik gözlemlenmesi, selülozik fraksiyon içerisinde ksilanın varlığına işaret etmektedir. Ayrıca $1450 \mathrm{~cm}^{-1}$ bölgesinde gözlemlenen bandında izole edilen $\alpha$-selülozik fraksiyonun yapısında az da olsa hemiselülozik fraksiyonların kaldığını kanıtlamaktadır. FTIR spektrumda saptanan bu sonuç izolasyon verimleri ile uygunluk içerisindedir. Çalışılan şartlarda biyokütle yapısındaki hemiselülozun tamamen kazanılamadığı, katı bakiyede kaldığı (selülozun bünyesinde) belirlenmiştir. Önceki çalışmalarda da selülozik fraksiyonda gözlemlenen bu iki temel pik hemiselülozun etkin bir şeklide uzaklaştırılamadığı (kazanılamadığı) şeklinde yorumlanmıştır [17, 31]. Şeker pancarı küspesi hariç elde edilen selülozik fraksiyonların yapısında $1534 \mathrm{~cm}^{-1}$ 'de pik tespit edilmiştir. Bu pik ligninin aromatik iskeletinin varlığına işaret etmektedir. Bu durum şeker pancarı küspesi hariç elde edilen selülozik fraksiyondan, ligninin de tamamen uzaklaştırılamadığı göstermektedir.

FTIR analiz sonuçları ve yorumları, lignin muhteviyatı kritik değerin üstünde olan biyoktle kaynakları için temel bileşenlerin izolasyonu için alkali ekstraksiyonun tek başına yeterli (etkin) olmadığ çıkarımını da kanıtlamaktadır.

\section{MORFOLOJİK ANALİZ SONUÇLARI}

Alkali ön işlem sırasında atık biyokütle kaynaklarının morfolojik yapısında meydana gelen değişimi ortaya koymak yani, alkali ön işlemin katı gözenekliliği artırdığını göstermek amacıyla, alkali ön işlem öncesi ve sonrası SEM görüntüleri Şekil 9'da sunulmuştur. Örnek biyokütle olarak çay posası seçilmiş olup, görüntülerin büyütme oranları x1000'dir.

Şekil 9(a)'dan, atık biyokütlenin yüzey morfolojisinin pürüzlü olduğunu, homojen ve kompakt bir yap1 sergilemediği görülmektedir. Atık biyokütlenin homojen olmayan az gözenekli yapısının, alkali ön işlem sırasında muamele edilen çözeltilerin yapıya difüzyonunu kolaylaştırdığı ve hızlandırdığı, böylelikle ekstraksiyon verimini artırdığı düşünülmektedir.
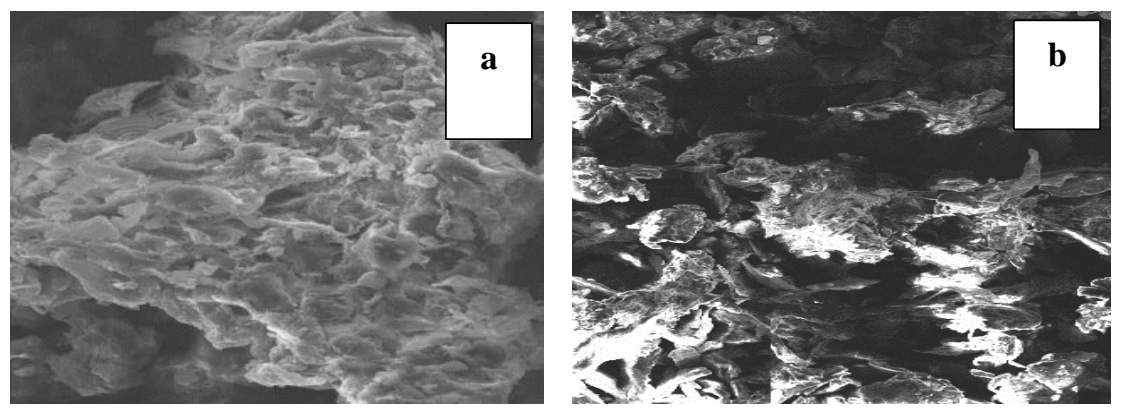

Şekil 9. Alkali ön işlem öncesi (a) ve sonrası (b) atık biyokütle örneğinin (çay posası) SEM görüntüsü (x1000) 
Elde edilen SEM görüntüleri literatür ile uyumlu olduğu saptanmıştı [39]. Alkali ön işlem sonucu elde edilen katı bakiyenin SEM görüntülerinden (Şekil 9(b)) gözenekli yapının belirgin ölçüde arttığı, yapının açıldığı saptanmıştır. Bu durum biyokütlenin hücre duvarının, alkali ön işlem muamelesi ile önemli ölçüde denatüre olduğu sonucu çıkarılmıştır.

\section{IV.SONUC}

Farklı kimyasal bileşime ve atık niteliğine sahip lignoselülozik yapılı atık biyokütle kaynaklarının (çay posası, kayısı çekirdeği kabuğu, ceviz kabuğu, şeker p. küspesi, talaş) sürdürülebilir biyo-rafineri yaklaşımıyla katma değeri yüksek ürünlere dönüşüm potansiyellerinin incelendiği çalışmada, elde edilen sonuçlar genel olarak aşağıdaki gibidir.

- Şeker pancarı küspesi diğer biyokütle türlerinden oldukça yüksek oranda (\%8.8) nem içeriğine sahiptir. Kayısı çekirdeği kabuğunun kül içeriği \%0.75 olup, diğer atıklara kıyasla oldukça düşüktür. Biyokütle örneklerinin sabit karbon içerikleri arasında belirgin bir fark yoktur, $\% 15$ ile \%19 arasında değişmektedir. Odun talaşının reçineli yapısından dolayı en yüksek uçucu madde orana ( \%77) sahip olduğu saptanmıştır.

- Biyokütle örneklerinin elementel analiz sonuçlarının genel olarak birbirlerine yakın olduğu, ancak çay posasının \% $\mathrm{N}$ içeriğinin (\%3.4) ve şeker pancarı küspesinin ise \%O içeriğinin (\%52.5) diğer atıklardan oldukça yüksek olduğu tespit edilmiştir.

- Lignoselülozik yapılı biyokütle atıklarının kimyasal analizi sonucunda, yaklaşık olarak \%5365 oranında holoselüloz, \%17-40 oranında ise ligninden oluştukları belirlenmiştir. Çay posasının \%hemiselüloz oranının (37.20), talaş numunesinin \%selüloz oranının (46.5) ve ceviz kabuğunun ise \%lignin oranının (36.90) diğer atıklardan çok daha yüksek olduğu belirlenmiştir.

- Ekstraktif maddelerin ayrıştırılma sürecinde en yüksek ekstraksiyon verimine odun talaş1 numunesinde (\%12.59), en düşük verime ise kayısı çekirdeği kabuğu (\%5.41) numunesinde ulaşılmıştır. Ekstraktif madde ekstraksiyon verimlerinin, hammaddelerin kimyasal analiz sonuçları ile tutarlılık gösterdiği belirlenmiştir.

- Sicak su ekstraksiyonu ile izole edilebilen hemiselüloz yüzdesi $\% 1.73$ ile $\% 2.65$, lignin yüzdesi ise \%0.01 ile \%0.37 aralığındadır. Suda çözünebilen hemiselüloz içeriği en düşük olan atık kayısı çekirdeği kabuğu, en yüksek olan ise şeker pancarı küspesidir. Suda çözünen lignin muhteviyatı en düşük olan atık çay posası, en yüksek olan atık ise kayısı çekirdeği kabuğudur.

- Alkali ekstraksiyon üzerine biyokütlenin etkisinin incelendiği adımda hemiselülozun izolasyon veriminin atıkların lignin muhteviyatından bağımsız davrandığı, ancak, biyokütlelerin lignin muhteviyatının lignin ekstraksiyon verimi üzerinde oldukça etkin bir rol oynadığı saptanmıştır. Hemiselüloz izolasyon verimlerinin hammadde temeli üzerinden $\% 24.58$ ile \%5.08, ligninin veriminin ise \%19.56 ile 13.11 aralığında değiştiği belirlendi.

- Elde edilen selülozik fraksiyonların FTIR spektrumları irdelendiğinde, ksilan ve lignin kalıntısı varlığını kanıtlayan pikler görüldüğü tespit edilmiştir. İzolasyonun etkin bir şekilde gerçekleştirilemediği, çalışılan biyokütle türleri için alkali ekstraksiyonun temel bileşenlerin izolasyonu için tek başına yeterli olmadığı, oksidatif ajan kullanılması gerektiği sonucuna varılmıștır.

Çalışma sonuçları atık biyokütle kaynaklarının biyo-ürünlere dönüşüm potansiyelinin yüksek olduğunu göstermiş̧tir. Türkiye, çok çeşitli tarımsal ürün çeşitliliğine sahip bir ülkedir. Tarımsal faaliyetler sonucunda büyük miktarda atık açığa çıkmaktadır. Biyokütle enerji potansiyeli atlasına (BEPA) göre, Türkiye yılda yaklaşık 62 milyon ton tarımsal atık rezervine sahiptir. Tarımsal faaliyetlerden daha fazla gelir elde etmek, çevreyi ve doğayı korumak ve sosyo-ekonomik kalkınmayı hızlandırmak için tarımsal atıkların toplanması ve değerlendirilmesi gerekmektedir. İlk bakışta, tarımsal atıkların toplanmasının ek maliyetlere yol açacağı düşünülse de, bu atıkların yüksek katma değerli biyo-ürünlere dönüştürülebilir olması, bu ilk maliyeti önemsiz kılmaktadır. Bu kapsamda, büyük ölçekli bir işletme için ekonomik sürdürülebilirlik ve uygulanabilirlik konusunda bu tarz çalışmaların sürdürülmesi gerektiği düşünülmektedir. 


\section{KAYNAKLAR}

[1] B. C. Saha, "Hemicellulose bioconversion," J Ind Microbiol Biotechnol, c. 30, ss. 279-291, 2003, doi: 10.1007/s10295-003-0049-x.

[2] M.S. Hasyierah Noor, M.M.D. Zulkali, K.I. Syahidah Ku, "Ferulic acid from lignocellulosic biomass: Review," Malaysian Universities Conferences on Engineering and Techonology, Malaysia 2008.

[3] Bahçegül, "Effect of Biomass Pretreatment Conditions on the Glucose and Biodegradable Film Production From Lignocellulosic Wastes," Ph.D. dissertation, Natural and Applied Sciences, Middle East Technical University, Ankara, Türkiye, 2013.

[4] M. Çopuroğlu, "Haşhaş sapı ve Pamuk Sapındaki Polisakkarit Bileşimlerinin Analizinin Yapılması," Yüksek lisans tezi, Fen Bilimleri Enstitüsü, Süleyman Demirel Üniversitesi, Isparta, Türkiye, 2004.

[5] Ö. Dinçtürk, "Haşhaş Sapı ve Pamuk Sapı Hemiselülozlarının Alkali $\mathrm{H}_{2} \mathrm{O}_{2}$ ile Fraksiyonel Ekstraksiyonu ve Bileşim Karakterizasyonu," Yüksek lisans tezi, Fen Bilimleri Enstitüsü, Süleyman Demirel Üniversitesi, Isparta, Türkiye, 2007.

[6] J. M. Fang, R.C. Sun, D. Salisbury, P. Fowler, J. Tomkinson, "Comparative Study of Hemicelluloses from Wheat Straw by Alkali and Hydrogen Peroxide Extractions," Polymer Degradation and Stability, c. 66, s. 3, ss. 423-432, 1999a.

[7] J.M. Fang, R. Sun, P. Fowler, J. Tomkinson, C.A.S. H1ll, "Esterification of Wheat Straw Hemicelluloses in the N, N- Dimethylformamide/Lithium Chloride Homogeneous system," Journal of Applied Polymer Science, c. 74, s. 9, ss. 2301-2311, 1999b.

[8] B. Sapc1, "Pamuk Saplarından Antioksidan ve Ksilitol Üretimi” Yüksek lisans tezi, Gida Mühendisliği Anabilim Dalı, Gaziosmanpaşa Üniversitesi, Tokat, Türkiye, 2012.

[9] J.X. Sun, X.F. Sun, Y.Q. Su, "Fractional Extraction and Structural Characterization of Sugarcane Bagasse Hemicelluloses," Carbohydrate Polymers, c. 56, s. 2, ss. 195-204, 2004 a.

[10] J.X. Sun, F.C. Mao, X.F. Sun, R.C. Sun, "Comparative Study of Hemicelluloses Isolated with Alkaline Peroxide from Lignocellulosic Materials," Journal of Wood Chemistry and Technology, c. 24, s. 3, ss. 239-262, 2004b.

[11] Toraman E. "Investigation of Alkaline Pretreatment Parameters on A Multi-Product Basis for the Co-Production of Glucose and Hemicellulose Based Films from Corn Cobs," Graduate Thesis, Natural and Applied Sciences, Middle East Technical University, Ankara, Türkiye, 2012.

[12] G. Usal, "Buğday tarlası atıklarından alkali hidroliz ile fenolik bileşiklerin üretimi ve üretim koşullarının optimizasyonu," Yüksek lisans tezi, Fen Bilimleri Enstitüsü, Gaziosmanpaşa Üniversitesi, Tokat, Türkiye, 2014.

[13] H. Y1lmaz, "Hemicellulose Extraction from Agro-Food Industrial Wastes and Its Application in Foods" M.S. thesis, Food Engineering Department, Middle East Technical University, Ankara, Türkiye, 2012.

[14] F. Xu, J.X. Sun, C.F. Liu, R.C. Sun, "Comparative Study of Alkali- and Acidic Organic SolventSoluble Hemicellulosic Polysaccharides from Sugarcane Bagasse," Carbohydrate Research, c. 341, s. 2, 253-261, 2006. 
[15] S. Li, S. Xu, L. Shuqin, Y. Chen, L. Qinghua, "Fast pyrolysis of biomass in free-fall reactor for hydrogen-rich gas," Fuel Processing Technology, c. 85, ss. 1201-1211, 2004.

[16] W. Lan, C.F. Liu, R.C. Sun, "Fractionation of Bagasse into Cellulose, Hemicelluloses, and Lignin with Ionic Liquid Treatment Followed by Alkaline Extraction," J. Agric. Food Chem., c. 59, ss. 86918701, 2011.

[17] J. Xu, J.J. Cheng, R.R. Sharma-Shivappa, J.C. Burns, "Sodium Hydroxide Pretreatment of Switchgrass for Ethanol Production," Energy Fuels, c. 24, ss. 2113-2119, 2010.

[18] K. Kucharska, P. Rybarczyk, I. Hołowacz, R. Łukajtis, M. Glinka, M. Kamiński, "Pretreatment of Lignocellulosic Materials as Substrates for Fermentation Processes," Molecules, c. 23, s. 11, ss. 29$37,2018$.

[19] A. Tutuş, Y. Kazaskeroğlu, M. Çiçekler, "Evaluation of Tea Wastes in Usage Pulp and Paper Production," BioResources, c. 10, s. 3, ss. 5407-5416, 2015.

[20] K.Wang, B. Wang, R. Hu, X. Zhao, H. Li, G. Zhou, L. Song, A. Wu, "Characterization of hemicelluloses in Phyllostachys edulis (moso bamboo) culm during xylogenesis," Carbohydr. Polym., c. 221 , ss. $127-136,2019$.

[21] Q. Cai, Z. Fan, J. Chen, W. Guo, F. Ma, S. Sun, Q. Zhou, "Dissolving process of bamboo powder analyzed by FT-IR spectroscopy,” Journal of Molecular Structure, c. 1171, ss. 639-643, 2018.

[22] A.K. Samanta, S. Senani, A.P. Kolte, M. Sridhar, K.T. Sampath, N. Jayapal, A. Devi, "Production and in vitro evaluation of xylooligosaccharides generated from corn cobs," Food and Bioproducts Processing, c. 90, ss. 466-474, 2012.

[23] S. Nizamuddin, H.A. Baloch, G.J. Griffin, N.M. Mubarak, A.W. Butto, R. Abro, S.A. Mazari, B.S. Ali, "An overview of effect of process parameters on hydrothermal carbonization of biomass," Renewable and Sustainable Energy Reviews, c. 73, ss. 1289-1299, 2017.

[24] A.E. Pirbazar1, N.R. Pargami, N. Ashja, M.S. Emami, "Surfactant-coated Tea Waste: Preparation, Characterization and its Application for Methylene Blue Adsorption from Aqueous Solution," $J$. Environ. Anal. Toxicol., c. 5, s. 5, ss. 1-11, 2015.

[25] J. Shi, J. Li, "Metabolites and Chemical Group Changes in the Wood Forming Tissue of Pinus Koraiensis under Inclined Condition,” BioResources, c. 7, s. 3, ss. 3463-3475, 2012.

[26] D. She, F. Xu, Z.C.Geng, R.C. Sun, G.L. Jones, M.S. Baird, "Physicochemical characterization of extracted lignin from sweet sorghum stem," Crop. Prod., c. 32, s. 1, ss. 21-28, 2009.

[27] B. Büyükdere, "Doğal atık materyal lignininden yüzey aktif madde eldesi," Yüksek lisans tezi, Fen bilimleri Enstitüsü, İstanbul Teknik Üniversitesi, İstanbul, Türkiye, 2011.

[28] X.F. Sun, Z. Jing, P. Fowler, Y. Wu, M. Rajaratnam, "Structural characterization and isolation of lignin and hemicelluloses from barley straw," Industrial Crops and Products, c. 33, ss. 588-598, 2011.

[29] I. Egüés, A. Eceiza, J. Labidi, "Effect of different hemicelluloses characteristics on film forming properties," Industrial Crops and Products, c. 47, ss. 331-338, 2013.

[30] J.X. Sun, X.F. Sun, H.Zhao, R.C. Sun, "Isolation and characterization of cellulose from sugarcane bagasse," Polymer Degradation and Stability, c. 84, ss. 331-339, 2004. 
[31] M. Brienzo, A.F. Siqueira, A.M.F. Milagres, "Search for optimum conditions of sugarcane bagasse hemicellulose extraction," Biochemical Engineering Journal, c. 46, ss. 199-204, 2009.

[32] R.C. Sun, J. Tomkinson, "Characterization of hemicelluloses obtained by classical and ultrasonically assisted extractions from wheat straw," Carbohydr. Polym., c. 50, ss. 263-271, 2002.

[33] A.U. Buranov, G. Mazza, "Lignin in straw of herbaceous crops," Industrial Crops and Products, c. 28 , ss. $237-259,2008$.

[34] R. Sun, J.M. Lawther, W.B. Banks, "Fractional and structural characterization of wheat straw hemicelluloses," Carbohydrrate Polymers, c. 49, ss. 415-423, 1999.

[35] D.Y. Corredor, "Pretreatment and enzymatic hydrolysis of lignocellulosic biomass, " Ph.D. dissertation, Biological and Agricultural Engineering, Kansas State University, Kansas, ABD, 2008.

[36] R. Sun, S. Hughes, "Fractional extraction and physico-chemical characterization of hemicelluloses and cellulose from sugar beet pulp," Carbohydrate Polymers, c. 36, ss. 293-299, 1998.

[37] A. Mandal, D. Chakrabarty, "Isolation of nanocellulose from waste sugarcane bagasse (SCB) and its characterization," Carbohydr. Polym., c. 86, ss. 1291-1299, 2011.

[38] M.W. Frey, L. Li, M. Xiao, T. Gould, "Dissolution of cellulose in ethylene diamine/salt solvent systems," Cellulose, c. 13, ss. $147-155,2006$.

[39] S.S. Dhage, S.K. Kulkarni, "Adsorption of Carbon Dioxide on Adsorbents Synthesized by Microwave Technique,” J. Chem. Eng. Process Technol., c. 6, ss. 1-5, 2015. 